\title{
Molecular charecterization of Avian Adeno virus causing Inclusion Body Hepatitis-Hydropericardium syndrome in broiler chickens of Anand, Gujarat, I ndia
}

\author{
KB Thakor*, CJ Dave, KS Prajapati, DT Fefar and BM Jivani \\ Department of Veterinary Pathology \\ Anand Veterinary College, Anand Agricultural University, Anand-388001, Gujarat, India. \\ *Corresponding author Email: drketanthakor@gmail.com \\ Received: 16-09-2011, Accepted: 18-10-2011, Published Online: 17-12-2011 \\ doi: $10.5455 /$ vetworld.2012.178-182
}

\begin{abstract}
Avian Adenovirus was isolated from naturally infected broiler chickens. Two Liversample were collected in glycerol saline from the birds came from Aman and Jankipoutry farm for the postmortem in the Dept. of pathology,Veterinary college,Anand(Gujarat). Extraction of viral DNA from infected liver tissues was done as per the method of Meuleman et al., (2001) with minor modifications. The amplified PCR analyzed by agarose gel electrophoresis indicated DNA fragments of approximately $890 \mathrm{bp}$ as expected by primer HexonA F \& HexonB R. PCR assay revealed presence of IBH-HPS virus in both samples. Obtained PCR product of both sample were subjected to DNA sequencing and obtained sequencing was compared with other matched sequince. On phylogenetic analysis using Clustal W program showed 3 major group like upper, middle and lower respectively. In the minor branch of upper group the AMAN and JANKI isolates were found to group with Fowl adenovirus 12 strain 380 and Fowl adenovirus 11 strain C2B, so AMAN and JANKI isolates indicating a new fowl adenovirus genotype.
\end{abstract}

Key Words: Hydropericardium syndrome, Avian Adenovirus, Polymerase Chain Reaction

To cite this article : Thakor KB, Dave CJ, Prajapati KS, Fefar DT. and J ivani BM (2012) Molecular charecterization of Avian Adeno virus causing Inclusion Body Hepatitis-Hydropericardium syndrome in broiler chickens in Anand, Gujarat, India., Vet. World. 5(3): 178-182, doi: 10.5455/vetworld.2012.178-182.

\section{I ntroduction}

The avian adenovirus infections are believed to cause heavy economic losses by increasing mortality in chicken, diminished weight gain, poor feed conversion, drop in egg production and poor egg quality. It may also be involved in immunosuppression leading to increase incidence of secondary infection (Sambrook et al., 1989).

A number of useful methods have been developed for the diagnosis of avian adenovirus infections, including virus isolation in cell culture (Cowen et al., 1978), indirect immunofluorescent assay, virus neutralization (Adair et al., 1980; Adair et al., 1986), enzyme linked immunosorbant assay and the double immunediffusion (Adair et al., 1980; Adair et al., 1986; Cowen, 1987). However, most of them are laborious and time-consuming. The main problem with any serological test for adenovirus is associated with the interpretation of results, as antibodies against adenoviruses are commonly found in the blood of both healthy and infected birds. Polymerase chain reaction (PCR) (Saiki et $a l ., 1985)$ has been applied as a rapid diagnostic tool for the detection of avian viral and bacterial pathogens (Nguyen et al., 1994; Ganesh et al., 2002; Dahiya et al., 2002).

This method is not only rapid, but also more sensitive and specific than other diagnostic tests. Utilizing most advanced techniques of molecular biology the hydroperi-cardium syndrome agent can be characterized in order to develop a highly specific vaccine and in turn providing a quick, reliable and specific diagnosis. This study deals with the molecular characterization of avian adenoviruses isolated in Anand Distrtict of Gujarat through a combination of PCR and DNA sequencing. 


\section{Materials and Methods}

Polymerase Chain Reaction: Viral DNA was extracted from infected liver sample using DNeasy Tissue Kit (QIAGEN) as per the manufacturer's protocol. For PCR $2 \mu$ l of DNA was amplified using 15pmol of each primer (Forward, 5'- CAA RTT CAG RCA GAC GGT -3' nucleotide positions 144-161; Reverse, 5'- TAG TGA TGM CGS GAC ATC AT -3' nucleotide positions 10411021). The gene encoding the Hexon protein of fowl adenovirus group-I was chosen for the selection of primers (Meulemans et al., 2001). The amplification was carried out in thermocycler by initial denaturation at $94^{\circ} \mathrm{C}$ for $5 \mathrm{~min}$ and 35 cycles of $94^{\circ} \mathrm{C}$ for $2 \mathrm{~min}, 60^{\circ} \mathrm{C}$ for $1 \mathrm{~min}$ and $72^{\circ} \mathrm{C}$ for 90 s, followed by final elongation at $72^{\circ} \mathrm{C}$ for $2 \mathrm{~min}$. The amplified product was electrophoretically separated in a submerged two percent agarose gel and visualized under ultraviolet light.

DNA sequencing of field isolate: Primers and unincorporated dNTPs present in PCR product of two field sample were removed by PCR purification kit (Perfectprep PCR cleanup 96- cat no. 955156013-Eppendorf). Cycle sequencing was performed following the instructions supplied along with Big Dye ${ }^{\circledR}$ Terminator v3.1 Cycle Sequencing Kit (Applied Biosystems). The reaction was carried out in a final reaction volume of $20 \mu \mathrm{l}$ using $200 \mu \mathrm{l}$ capacity thin wall PCR tube. The reaction was carried out in a final reaction volume of $20 \mu \mathrm{l}$ using $200 \mu \mathrm{l}$ capacity thin wall PCR tube. The tubes containing the mixture were tapped gently, spun briefly and then were transferred to thermal cycler. The cycling protocol was designed for 28 cycles with the thermal ramp rate of 100C per second as as Initial denaturation was carried out at $94^{\circ} \mathrm{C}$ for $5 \mathrm{~min}$ followed by $30 \mathrm{sec}$ denaturation at $94^{\circ} \mathrm{C}, 10 \mathrm{sec}$ at $60^{\circ} \mathrm{C}$ for annealing and $4 \mathrm{~min}$ at $72^{\circ} \mathrm{C}$ for extension. After the reaction, the extension products were purified by using Ethanol-EDTA purification method. Electrophoresis and data analysis was carried out on the automated ABI PRISMTM 310 Genetic Analyzer (Applied Biosystems, USA) using appropriate Module, Basecaller, Dyeset/Primer and Matrix files. The nucleotide sequences of the Hexon protien gene obtained through ABI
PRISMTM 310 Genetic Analyzer by using forward and reverse primers were assembled for analysis by SeqScapeV2.5 software programme and a consensus sequence was obtained. Consensus sequence thus obtained was aligned with various published sequences of the Hexon protein gene (Table-1) in Genbank using NCBI Blast and CLUSTAL W (1.82) software programmes. All the nucleotide sequences were aligned for phylogenic analysis using the Clustal W program.

\section{Results and Discussion}

Detection of Fowl adenovirus by PCR: The PCR products generated was confirmed for their expected size $(897 \mathrm{bp})$ in $2 \%(\mathrm{w} / \mathrm{v})$ agarose gel in $0.5 \mathrm{X}$ TBE buffer as per the method of Sambrook et al. (1989) using horizontal submarine electrophoresis apparatus (Bangalore Genei, India). The amplified PCR analyzed by Agarose gel electrophoresis indicated a DNA fragment of approximately 890 bp as expected by primer HexonA F \& HexonB R (Fig.1). This was compared with 500 bp ladder marker. No DNA fragments were detected visually in ethidium bromide stained agarose gel electrophoresis when PCR was carried out from DNA extracted from tissues of healthy bird.

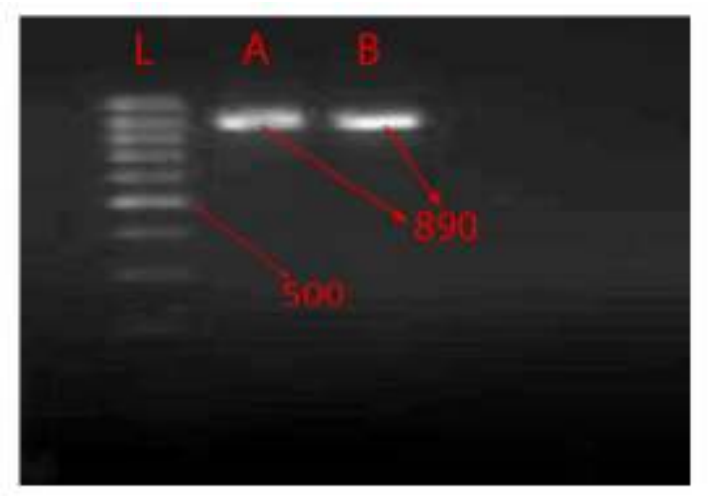

Fig 1. Agarose gel electrophoresis showing PCR amplified product (890) of field isolates.

The similar result was obtained by Meulemans et al., (2001) using same primer. PCR were record by Steer et al.,(2009) using same primer of present study of the 12 reference serotypes with the exception of FAdV-5, which 
Molecular charecterization of Avian Adeno virus causing Inclusion Body Hepatitis-Hydropericardium syndrome

Table-1. I BH virus strains used for comparison (Published sequences)

\begin{tabular}{|c|c|c|c|}
\hline Strain & GenBank Accession No. & Strain & GenBank Accession No. \\
\hline $\begin{array}{l}\text { FAV1- CELO } \\
\text { FAV2- ATCC VR-827 } \\
\text { FAV3- ATCC VR-828 } \\
\text { FAV4 } \\
\text { FAV5-ATCC VR-830 } \\
\text { FAV6- ATCC VR-831 } \\
\text { FAV7-ATCC VR-832 } \\
\text { FAV8 } \\
\text { FAV9- ATCC VR-834 } \\
\text { FAV10- ATCC VR-835 } \\
\text { FAV11- X11 } \\
\text { FAV12- } 380 \\
\text { FAV5-TR 22 } \\
\text { Duck adenovirus-1(AAV-EDS) }\end{array}$ & $\begin{array}{l}\text { AF339914 } \\
\text { AF339915 } \\
\text { AF339916 } \\
\text { AJ431719 } \\
\text { AF339919 } \\
\text { AF339921 } \\
\text { AF339922 } \\
\text { AF339918 } \\
\text { AF508958 } \\
\text { AF339924 } \\
\text { AF339920 } \\
\text { AF339925 } \\
\text { AF508953 } \\
\text { Y09598 }\end{array}$ & $\begin{array}{c}\text { FAV8- TR } 59 \\
\text { FAV9- } 764 \\
\text { FAV4- KR5 } \\
\text { FAV2- } 685 \\
\text { FAV3- } 75 \\
\text { FAV4- } 506 \\
\text { FAV5- } 340 \\
\text { FAV6- CR119 } \\
\text { FAV7- YR36 } \\
\text { FAV8- 58 } \\
\text { FAV11- C2B } \\
\text { Turkey adenovirus-3(HE virus) } \\
\text { Duck adenovirus-1(AAV-EDS) }\end{array}$ & $\begin{array}{l}\text { AF508956 } \\
\text { AF508958 } \\
\text { AF508951 } \\
\text { AF508947 } \\
\text { AF508949 } \\
\text { AF508950 } \\
\text { AF508952 } \\
\text { AF508954 } \\
\text { AF508955 } \\
\text { AF508957 } \\
\text { AF508959 } \\
\text { AF074949 } \\
\text { Y09598 }\end{array}$ \\
\hline
\end{tabular}

Table-2. Matched Fow I adenovirus D I solates

\begin{tabular}{lccc}
\hline Sr.no & GenBank Accession no & Fowl adenovirus D Isolates & Matching percentage (\%) \\
\hline 1. & EF685519.1 & $04-52482$ & 94 \\
2. & EF685467.1 & $04-60057-922$ & 94 \\
3. & EF685579.1 & $04-40373$ & 95 \\
4. & EF685576.1 & $04-40372$ & 95 \\
5. & EF685646.1 & $06-30487$ & 95 \\
6. & EF685526.1 & $04-52446$ & 95 \\
7. & EF685514.1 & $04-52487$ & 95 \\
8. & EF685659.1 & $04-23825-13$ & 94 \\
9. & EF685495.1 & $04-53357-116$ & 94 \\
10. & EF685491.1 & 94 \\
\hline
\end{tabular}

showed low-level or no amplification with the Hexon A/B primer set.

DNA sequencing and phylogenetic analysis of field isolate: Sequencing can be performed on any part of the genome, but was usually performed on a selected part of the Hexon protein gene (Meulemans et al., 2001). Using the blast programme of NCBI the obtained nucleotide sequences of both samples( AMAN \& JANKI) were found to have $94 \%$ identity with fowl adenovirus 11 isolate 1047 hexon protein gene(Accession no DQ323984.1), 94\% identity with Fowl adenovirus 11 isolate FAdV11/Brazil/2006/USP-0 (Accession no Fj3607 47.1) and also Fowl Adenovirus D of different isolates show different percentage of identity with AMAN and JANKI isolates that shown in Table no.2.

For comparison nucleotide sequences of other Fowl Adenovirus isolates were retrieved from the Genbank database shown in Table no. 2. Nucleotide sequences of the Hexon protien gene of the isolates from Aman P.F. and Janki P.F. were aligned with other isolates in the Clustal W program. Phylogenetic analysis of nucleic acid sequence was done with foreign isolates and tree diagram created (Fig.2).

On phylogenetic analysis using Clustal W program showing 3 major group like upper, middle and lower respectively (Fig.2). Within the uppers group, 2 minor branches were observed. In the minor branch of upper group the AMAN and JANKI isolates were found to group with Fowl adenovirus 12 strain 380 and Fowl adenovirus 11 strain C2B. However, within this major upper group, a minor branch was formed by AMAN and JANKI isolates indicating a new fowl adenovirus genotype. FAV6-CR119 Strain could not be assigned to any clusters within groups and might be a representative third cluster (Lower group). The different strains like FAV11-X11, FAV7ATCC, FAV9-764, FAV7-YR36 etc. are involved in the minor branches of middle group.

The sequencing of sample M158-04 was carried out by Raue et.al., (2005) and the overall percentage of identity among the sequences obtained from the FAdV reference strains and M158-04 ranged between 60.3 to $67.0 \%$, whereas 


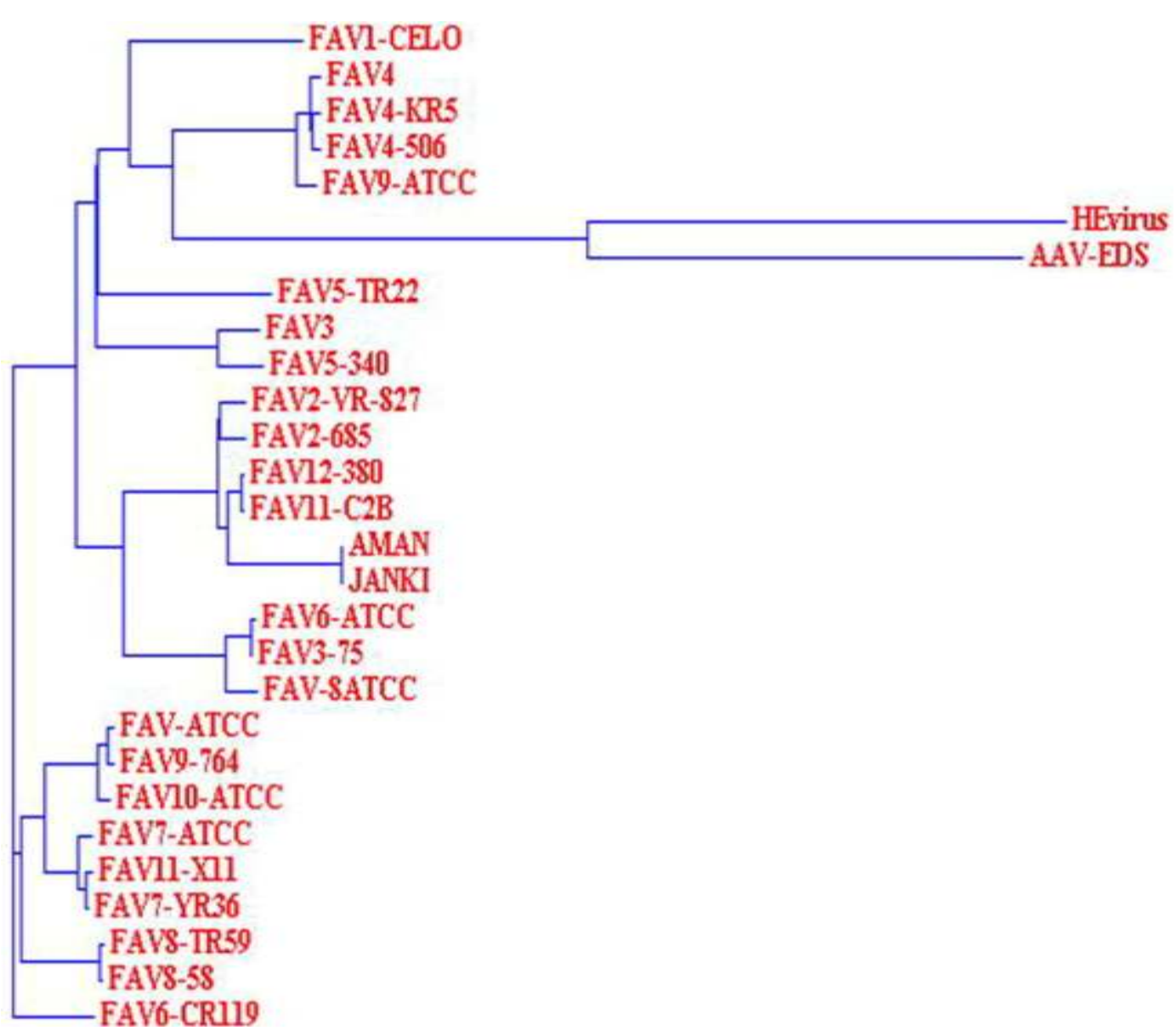

Figure-2 Phylogenetic tree based on nucleotide sequnces of Hexon Gene of field isolates and sequnces from Gene bank.

that of the TAdV3 sequence and M158-04 was only $14.1 \%$. With $12.5 \%$, the sequence of EDSV showed the lowest percentage of identity when compared with that of M158-04. A phylogenetic tree was established, showed 3 major branches for the proposed genera, Aviadenovirus(FAdV1-12), Atadenovirus (EDSV) and Siadenovirus. Within the Aviadenovirus branch, 7 minor branches were observed. However, within this major branch a sole minor branch was formed by M158-04 indicating that M158-04 represents a new avian adenovirus genotype.

\section{Acknowledgments}

The Authors would like to thanks the all staff as well as the assistant and workers of the Department of Veterinary Pathology, Anand
Veterinary College, Anand Agricultural University, Anand, Gujarat, for their help and support.

\section{Conflict of interest}

Authors declare that they have no conflict of interest.

\section{References}

1. Adair, BM; McFerran, JB and Calvert, VM (1980). Development of a microtitre fluorescent antibody test for serological detection of adenovirus infection in birds. Avian Pathol., 9:291-300.

2. Adair, BM; Tood, D; Mcferran, JB and Mckillop, ER (1986). Comparative serological studies with egg drop syndrome virus. Avian Pathol., 15: 677-685. 
Molecular charecterization of Avian Adeno virus causing Inclusion Body Hepatitis-Hydropericardium syndrome

3. Cowen, BS (1987). A trivalent antigen for the detection of type 1 avian adenovirus precipitin. Avian Dis., 31:351-354.

4. Cowen, BS; Mitchell, GB and Calnek, BW (1978). An adenovirus survey of poultry flocks during the growing and laying periods. Avian Dis., 22: 115-121.

5. Dahiya S., R.N. Srivastava, M. Hess and B.R. Gulati (2002): Fowl adenovirus serotype 4 associated with outbreaks of infectious hydropericardium in Haryana, India. Avian Dis., 46:230-233.

6. Ganesh, K; Suryanarayana, V.V. and Raghavan, R (2002). Detection of fowl adenovirus associated with hydropericardium hepatitis syndrome by a polymerase chain reaction. Vet. Res. Commun., 26: 73 80.

7. Nguyen, AV; Khan, MI and Liu, Z (1994). Amplification of salmonella chromosomal DNA using the polymerase chain reaction. Avian Dis., 38: 119-126.

8. Saiki, RK; Sckarf, S; Faloona, F; Mullis, KB; Horn, GT; Erlich, HA and Arnheim, N (1985). Enzymatic amplification of betaglobulin genomic sequence and restriction site analysis for diagnosis of sickle cell anemia. Science. 230: 1350-1354.

9. Sambrook, J., Fritsch, E.F. and Maniatis, T., (1989). Molecular Cloning: A Laboratory Manual, $2^{\text {nd }}$ edn, (Cold Spring Harbor Laboratory Press, New York). 